УДК 616.14.-005.6.-02:616.14.-007.64-085.849.19-089.819.7-06]-089

\title{
Результати лікування термоіндукованого тромбозу після ендовазальної лазерної абляції варикозних вен
}

\author{
Б.О. Матвійчук, Н.Р. Федчишин \\ bmatviychuk@yahoo.com
}

Львівський національний медичний університет імені Данила Галищького, Львів

\section{Реферат}

Вступ. Ендовазальна лазерна коагуляція підшкірних вен - домінуюче операційне втручання у сучасній флебології. Однак, незважаючи на доведену безпечність методу, існує ряд післяопераційних ускладнень, таких як ендовенозний термоіндукований тромбоз.

Мета дослідження. Оцінити післяопераційні результати ЕТIT після ендотермальних методів лікування варикозної хвороби.

Матеріали та методи. Науковим дослідженням охоплено 278 пацієнтів, оперованих в клініці 3 приводу варикозної хвороби (BX) великої та малої підшкірної вени за період з 1.03.2016 по 16.06.2018рр. Загалом, за класифікацією Кabnick ETIT першого класу верифіковано у 11 (3,9\%) пацієнтів, другого - у 6 (2,1\%), третього - у 2 $(0,7 \%)$. Четвертого класу (Kabnick IV), при якому відбувається повна облітерація тромбом загальної стегнової та стегнової вени - не було.

Результати досліджень та їх обговорення. Аналіз отриманих результатів свідчить про високу ефективність методу ЕВЛК у лікуванні ВХ. Проте, слід відмітити про певний ризик трансфасціального переходу термоіндукованого тромбозу (6,8\%) на систему глибоких вен 3 можливою міграцією тромботичних мас в легеневу артерію. Повний регрес ускладнення спостерігали у всіх оперованих на 5 добу після втручання, симптоматичних та фатальних тромбоемболічних ускладнень не було.

Висновки. Малоінвазивні термооблітераційні методи лікування варикозної хвороби є ефективним та безпечним методом лікування. Низький рівень ендовазального термоіндукованого тромбозу $(6,8 \%) \epsilon$ добрим результатом лікування, однак потребує подальшого вивчення. Антикоагулянтна терапія є успішною в усіх пацієнтів 2-4 класу ETIT за класифікацією Kabnick протягом 30 днів

Ключові слова: варикозна хвороба, ендовазальна лазерна коагуляція, ендовенозний термоіндукований тромбоз.

Evaluation of risk of venous thromboses after endovenous laser therapy in patients with varicose disease Matviychuk B.O., Fedchyshyn N.R.

Danylo Halytsky National Medical University, Lviv

Introduction. Endovenous laser ablation (EVLA) of saphenous veins is dominant surgical intervention in modern phlebology. However, despite, proven safety of the method, there is a number of postoperative complication head-induced triatment thrombosis of varicose disease.

The aim of the study. Evaluation of postoperative results of EVLA after endothermal methods of treatment of varicose veins.

Materials and methods. Scientific research covered 278 patients operated in a clinic for varicose disease great saphenous vein from 1.03.2016 - 16.06.2018. In general by classification Kabnick EHIT first class is verified in $11(3,9 \%)$ patients, second - in $6(2,1 \%)$, third - in $2(0,7 \%)$. Fourth class (Kabnick IV) at which there is a complete of the deep vein thrombosis and pulmonary embolism - it was not.

Results and discussion. The analysis of the obtained results testifies to the high efficiency of the method of EVLA in the treatment of varicose disease. However, it should be noted that there is a certain risk of transfascial transition of head-induced thrombosis $(6,8 \%)$ to the system of deep veins with the possible migration of thrombotic masses to the pulmonary artery. Complete regression of complications was observed in all operated patients for 5 day after intervention. There were no symptomatic and thromboembolic complication.

Conclusions. Mini-invasive thermoblittering treatments for varicose veins are an effective and safe method of treatment. The low level of endovascular thermoinduced thrombosis $(6.8 \%)$ is a good result of treatment, but needs to be further studied. Anticoagulation therapy is successful in all patients in the 2nd-4th grade of EVLA according to the Kabnick classification within 30 days.

Key words: endovenous laser ablation, varicose disease, head-induced treatment thrombosis

Вступ. Ендовазальна лазерна коагуляція (ЕВЛК) підшкірних вен - домінуюче операційне втручання у сучасній флебології, визнане Свропейським венозним форумом 3 найвищим ступенем доказовості як втручання з однаковою ефективністю у порівнянні з класичним стріпінгом підшкірних вен [1]. Доведено, що беззаперечною перевагою ендотермальних методик $\epsilon$ його малоінвазійність, i, як наслідок, кращий косметичний ефект, можливість виконання втручання без наркозу, термін перебування в стаціонарі менше доби та короткий період післяопераційної непрацездатності та реабілітації $[1,2,4]$.

Однак, незважаючи на доведену безпечність методу, існує ряд післяопераційних ускладнень, таких, як - розлеглий інфільтрат в проекції вени після ендотермальної облітерації, парестезії та незначні опіки в місцях проходження файберу. Проте, найгрізніше 
післяопераційне ускладнення, що може привести до тяжких наслідків, таких, як тромбоз глибоких вен або тромбоемболія легеневої артерії є ендовенозний термоіндукований тромбоз (ЕTIT).

Багатоцентрове проспективне дослідження, в основу якого лягли дані медичних центрів в Vein Institute of New Jersey (USA), Miami Vein Center (USA), Day Surgery Center (Padua, Italy) та охопило більше 2-ох тисяч процедур термооблітерації, виявило 78 (2,9\%) випадків ЕТІТ - 92\% після абляції великої підшкірної вени (ВПВ) та $8 \%$ - малої підшкірної вени (МПВ) [3,4]. За ходом дослідження на Американському венозному форумі у 2006 році L. Kabnick була запропонована чотирьохступенева класифікація ЕТIT, яка не втратила своєї актуальності до сьогодні [3].

Мета дослідження. Оцінити післяопераційні результати ЕТІТ після ендотермальних методів лікування варикозної хвороби.

Матеріали та методи. Науковим дослідженням охоплено 278 пацієнтів, оперованих в клініці 3 приводу варикозної хвороби (ВХ) великої та малої підшкірної вени за період 3 1.03.2016 по 16.06.2018pp. Середній вік - 45,3 $\pm 10,9$ років, переважали жінки - 71,3\%. За СЕАР до С2 кваліфіковано 89 (32,0\%) пацієнтів, С3 - 93 (33,5\%), С4 - 57 (20,5\%), С5 - 21 (7,6\%), С6 - 18 (6,4\%). Середній діаметр великої підшкірної вени (ВПВ) в середній третині стегна $1,2 \pm 0,3$, в ділянці сафенофеморального гирла (СФГ) під місцем впадіння vena epigastrica superficialis $-1,1 \pm 0,2 \mathrm{~cm}$.

Критеріями включення в наукове дослідження були: клінічні групи С2-С6 за СЕАР, діаметр ВПВ на стегні до 1,5 см, вік 318 років, поінформована згода пацієнта. Критеріями виключення: гострий чи хронічний тромбоз підшкірних вен, захворювання артерій нижніх кінцівок (КПІ $\leq 0,9)$, рецидив $\mathrm{BX}$, постійна терапія антикоагулянтами та доведена тромбофілія, рак чи вагітність на момент обстеження.

За ходом втручання, під контролем ультрасонографії (УСГ), усім пацієнтам виконано тумінісцентну гідрокомпресію за ходом ВПВ охолодженим до $5^{\circ} \mathrm{C}$ фізіологічним розчином. Всі операційні втручання виконано однією бригадою хірургів, діодним лазерним коагулятором 1470 нм, в постійному або імпульсному режимі випромінювання, радіальним однорінговим світловодом, потужністю 8-10 Вт. Початок абляції вени - 2 см від СФГ. У 78\% ЕВЛК доповнено мініфлебектомією, кросектомію не виконували. Тривалість втручання $48,7 \pm 21,9$ хв, термін перебування в стаціонарі $12,8 \pm 9,7$ годин. Після ЕВЛК виконували УСГ на апараті GE Logiq Book XP ${ }^{\circledR}$ на першу, п’яту та десяту добу.
Після УСГ візуалізації термінального закінчення світловода, відступали 1-1,5 см дистальніше від термінального клапану та вводили охолоджений ізотонічний розчин в ділянці СФГ з метою вирівнювання кута впадіння ВПВ в стегнову, як метод додаткової протекції процесу вапоризації та травмування глибоких судин.

Загалом, за класифікацією Kabnick [3] ETIT першого класу верифіковано у 11 (3,9\%) пацієнтів, другого - у $6(2,1 \%)$, третього - у $2(0,7 \%)$. Четвертого класу (Kabnick IV), при якому відбувається повна облітерація тромбом загальної стегнової та стегнової вени - не було. Сумарний результат усіх термоіндукованих тромбозів - $19(6,8 \%)$, клінічно вагомих та фатальних тромбоемболій легеневої артерії не було.

Результати досліджень та їх обговорення. Аналіз отриманих результатів свідчить про високу ефективність методу ЕВЛК у лікуванні ВХ. Проте, слід відмітити про певний ризик трансфасціального переходу термоіндукованого тромбозу $(6,8 \%)$ на систему глибоких вен 3 можливою міграцією тромботичних мас в легеневу артерію. Отримані результати корелюють 3 даними венозного центру Нью-Йоркського університету (2014), де частота ETIT (Kabnick I-II), залежить від здобуття досвіду термооблітерації, та зменшилась 3 5,2\% (перший рік) до 0,4\% (третій рік). Незначно вищі показники ЕТIT в нашому дослідженні пояснюємо становленням методики, більш занедбаними формами ВХ, де клас С5-С6 відмічено у 14\% пацієнтів та обмеженим фінансуванням 3 неможливістю рутинного використовування сучасних радіальних світловодів 3 подвійним кільцем (Biolitec 2 Ring®).

Вважаємо, що 1-2 клас ЕТІТ є контрольованим процесом та безпечним щодо можливих фатальних наслідків. Однак, враховуючи останні рекомендації консервативного лікування тромбозу підшкірних вен нижніх кінцівок усім пацієнтам з ЕTIT 2 та ЕTIT 3 призначили терапію пероральними антикоагулянтами терміном на 30 днів. У пацієнтів першого класу обмежились динамічним УСГ спостереженням. Повний регрес ускладнення спостерігали у всіх оперованих на 5 добу після втручання, симптоматичних та фатальних тромбоемболічних ускладнень не було.

Висновки. Малоінвазивні термооблітераційні методи лікування варикозної хвороби $є$ ефективним та безпечним методом лікування. Низький рівень ендовазального термоіндукованого тромбозу $(6,8 \%)$ є добрим результатом лікування, однак потребує подальшого вивчення. Антикоагулянтна терапія $€$ успішною в усіх пацієнтів 2-4 класу ETIT за класифікацією Kabnick протягом 30 днів.

Інформація про конфлікт інтересів. Автори заявляють про відсутність конфлікту інтересів при виконанні наукового дослідження та підготовці даної статті.

Інформація про фінансування. Автори гарантують, що вони не отримували жодних винагород в будь-якій формі, здатних вплинути на результати роботи. 
Особистий внесок кожного автора у виконання роботи:

Матвійчук Б.О. - розробка концепції і дизайну дослідження, аналіз отриманих даних, редагування;

Федчишин Н.P. - збір матеріалу дослідження, аналіз отриманих даних, статистичний аналіз, підготовка тексту статті.

\section{Список використаної літератури}

1. Quarto G. Comparison of traditional surgery and laser treatment of incontinent great saphenous vein. Results of a meta-analysis. Ann Ital Chir. 2016;87:61-7.

2. Vähäaho S. Five-year follow-up of a randomized clinical trial comparing open surgery, foam sclerotherapy and endovenous laser ablation for great saphenous varicose veins. Br J Surg. 2018 May;105(6):686-91. DOI: 10.1002/bjs. 10757.

3. Almeida J. Management trends for chronic venous insufficiency across the United States: A report from the American Venous Registry. J Vasc Surg Venous Lymphat Disord. 2013 Jan;1(1):100. DOI: 10.1016/j.jvsv.2012.10.006.

4. Dexter D. Complications of endovenous lasers. Phlebology. 2012 Mar;27(1):40-5. DOI: 10.1258/phleb.2012.012S18.

Стаття надійшла до редакції: 24.10.2017 p. 